Situs Jurnal : $\underline{\text { http://ejournal.stiepancasetia.ac.id/index.php/jieb }}$

Jilid 7 Nomor 2 Juli 2021

Hal 179-189

\title{
PERKEMBANGAN PERAN MAHASISWA UNIVERSITAS ISLAM MAJAPAHIT TERHADAP KEGIATAN EKONOMI ISLAM
}

\section{Dina Dwi Silvialorensa, Eka Qurrotul Aini, Sindy Khoirunnisa}

\begin{abstract}
The background of this research is the lack of students understanding of Islamic economics and to find out the role of students in the development of Islamic economics within the University. The development of Islamic economics can increase, if students can apply Islamic economics well. Students are believed to be the nation's successors who are genius, creative and intelligent, have a high spirit of spirit that can foster a sense of self-confidence. In Indonesia itself, the sharia economy is growing over time, and it has been proven because there are practices such as debt by contract without usury. The business that is currently trending in Indonesia is online buying and selling contracts, because it is considered more practical. In Indonesia, there are also many Islamic banks based on the Qur'an and hadith that have been set by the Indonesian Ulema Council (MUI). With this research, students have an awareness of the importance of Islamic economics and can apply it both in the university environment and in the general environment.
\end{abstract}

\section{Keywords: Student, Islamic economics, Indonesian Council of Ulama}

Abstrak: Yang melatar belakangi penelitian ini adalah karena kurangnya pemahaman mahasiswa terhadap ekonomi Islam, rendahnya minat ketertarikan untuk mempelajari ekonomi Islamsertauntuk mengetahui peran mahasiswa terhadap perkembangan ekonomi Islam di lingkungan Universitas. Perkembangan ekonomi Islam bisa meningkat, jika mahasiswa dapat menerapkan ekonomi Islam dengan baik. Mahasiswa diyakini sebagai penerus bangsa yang jenius, kreatif dan cerdas, memiliki jiwa semangat tinggi yang dapat menumbuhkan rasa kepercayaan diri. Di Indonesia sendiri ekonomi syariah semakin berkembang seiring berjalannya waktu, dan telah terbukti karena terdapat praktik seperti berhutang dengan akad tanpa adanya riba. Bisnis yang saat ini sedang trending di Indonesia yaitu akad jual beli online, karena dinilai lebih praktis. Di Indonesia juga sudah banyak bank syariah yang didasarkan pada Al-Qur'an dan hadits yang telah ditetapkan oleh Majelis Ulama Indonesia (MUI). Dengan adanya penelitian ini, menjadikan mahasiswa memiliki kesadaran tentang pentingnya ekonomi Islam dan dapat menerapkannya baik di lingkungan Universitas maupun di lingkungan umum.

Kata kunci: Mahasiswa, Ekonomi Islam, Majelis Ulama Indonesia 


\section{PENDAHULUAN}

\subsection{Latar Belakang}

Diambil dari bahasa Arab "Almu'amalah al-maddiyah" yang dinamakan ekonomi merupakan sebuah aturan mengenai pergaulan dan perhubungan manusia untuk kehidupannya. Dan dalam istilah lain al-iqtishad merupakan kehidupan manusia diatur dengan sehemathematnya dan secermat-cermatnya. Banyak juga pengertian ekonomi Islam dikalangan pakar ekonomi Islam. MohammadNejatullah Siddiqiberpendapat bahwa ekonomi Islam adalah tantangan ekonomi pada zamannya merupakan jawaban dari pemikir muslim yang berdasar pada Al-Qur'an, sunnah, akal pikiran dan pengalaman. Ekonomi Islam menurut $\mathrm{M}$. Abdul Mannan, yaitu ilmu sosial berdasarkan nilai-nilai Islam yang mempelajari tentang masalah perekenomian rakyat. Sama halnya yang dikemukakan oleh M.M. Metwally, ekonomi Islam adalah ilmu yang mempelajari perilaku orang muslim sesuai dengan Al-qur'an, Hadis Nabi, ijma' dan qiyas. (Dr. Mardani,, 2017:179).

Menurut Soerjono Soekanto (2002:243) peranan merupakan aspek dinamis kedudukan (status). Seseorang menjalankan perannya dengan hak dan kewajibannya sesuai dengan kedudukannya. Peran diartikan sebagai perilaku yang diatur dan diharapkan seseorang dalam posisi tertentu.

Menurut Knopfemacher mahasiswa merupakan calon pemuda terdidik yang terlibat dalam suatu perguruan tinggi (semakin menyatu dengan lingkungan masyarakat), diajar dan diandalkan untuk menjadi sosok yang cerdas dan terpelajar. (Suwono, 1978:35)

Dari paparan di atas maka yang melatar belakangi adanya peran mahasiswa terhadap kemajuan perekonomian islam adalah belum terbentuknya pengetahuan dan kurangnya pemahaman mahasiswa terhadap perkembangan ekonomi islam di Universitas Islam Majapahit. Dengan itu penulis melakukan wawancara secara virtual pada hari Senin tanggal 10 Mei 2021 terhadap beberapa mahasiswa untuk mengetahui peran mahasiswa terhadap perkembangan ekonomi islam di Universitas Islam Majapahit.

Sehingga dapat disimpulkan bahwa mahasiswa harus memerankan dan memimpin dalam praktik ekonomi syariah, mahasiswa memberikan edukasi kepada masyarakat umum, secara keseluruhan mahasiswa dianggap lebih tanggap dalam menguasai ekonomi syariah daripada golongan masyarakat umum dan juga mahasiswa harus bisa memberikan dorongan kepada masyarakat umum dalam mempelajari dan menerapkan sistem ekonomi syariah dalam kehidupan seharihari. Peran Mahasiswa juga dapat dipengaruhi oleh segi pendorong dan penghambat.

\subsection{Rumusan Masalah}

1. Bagaimana peran mahasiswa Fakultas Ekonomi Universitas Islam Majapahit terhadap perkembangan ekonomi Islam?

2. Faktor-faktor apa saja yang menjadi pendorong dan penghambat terhadap perkembangan ekonomi Islam pada Fakultas Ekonomi Universitas Islam Majapahit?

\subsection{Tujuan Penelitian}

1. Untuk mengetahui peran mahasiswa Fakultas Ekonomi Universitas Islam Majapahit terhadap perkembangan ekonomi Islam.

2. Untuk mengetahui faktor-faktor pendorong dan penghambat terhadap perkembangan Ekonomi Islam pada Fakultas Ekonomi Universitas Islam Majapahit.

\subsection{Kajian Teori}

A. Peran

Teori peran merupakan teori yang diajukan oleh Khan et al. (1964). Teori peran adalah sebagai 
aktor sosial yang menekankan sifat individu dengan mempelajari perilaku yang sesuai dengan lingkungan sosial. (Khan et al., 1964)." Peran ini bermakna, yaitu tingkat khusus yang harus dimiliki oleh setiap masyarakat umum. (Kamus Besar Bahasa Indonesia, 2007: 845) "Peran termasuk bagian dari tugas pokok yang harus diselesaikan".

Definisi peran menurut Pakar :

1. Soerjono Soekanto (2002:243) berpendapat bahwa peran adalah bagian yang khusus dari suatu jabatan, jika seseorang memenuhi hak-hak istimewa dan kewajibannya sesuai dengan kedudukannya, maka dapat dikatakan bahwa itu sudah memenuhi suatu peran. Setiap orang memiliki kualitas yang berbeda-beda dalam menyelesaikan kewajiban, komitmen dan tugasnya dalam suatu organisasi.

2. Menurut Biddle dan Thomas dalam Sarwono (2015:224), peran adalah suatu bentuk ungkapan bagi pemegang posisi yang diharapkan untuk membatasi perilaku tertentu.

3. Menurut Suhardono (1994:15), peran adalah tolak ukur yang digunakan untuk membatasi perilaku yang harus dilakukan seseorang selama memegang jabatan tertentu.

Dari berbagai pengertian di atas, dapat disimpulkan bahwa peran itu bagian penting dari tugas utama, mempunyai kedudukan, dan merupakan batasan tingkah laku seseorang.

B. Mahasiswa

Definisi mahasiswa menurut para ahli:
1. Mahasiswa adalah seseorang yang sedang menempuh pendidikan pada satu jenis perguruan tinggi yang terdiri dari akademis, politeknik, sekolah menengah, yayasan dan perguruan tinggi (Hartaji, 2012:5).

2. Menurut Siswoyo (2007:121) mahasiswa adalah orang yang sedang menempuh pendidikan pada jenjang perguruan tinggi negeri dan swasta serta berbagai instansi yang setingkat dengan perguruan tinggi. Mahasiswa dianggap memiliki wawasan dalam penalaran dan aktivitas yang cepat. Dasar penalaran dan tindakan yang cepat dan tepat merupakan karakteristik alami pada setiap siswa.

3. Mahasiswa adalah seseorang dengan usia sekitar 18 - 25 tahun, yang dapat disebut remaja akhir sampai dewasa awal, tugas pembinaan usia siswa ini adalah untuk mengatur kedudukan kehidupan sehari-hari (Yusuf, 2012: 27).

Dari berbagai pengertian di atas, secara umum mahasiswa adalah seseorang yang menempuh pendidikan di perguruan tinggi, baik negeri maupun swasta, untukmenyusun tujuan dan menata kehidupan di kemudian hari.

\section{Ekonomi Islam}

Definisi Ekonomi Islam dari beberapa sumber buku :

1. Sesuai Monzer Kahfi dalam bukunya "The Islamic Economy" menjelaskan tentang masalah keuangan Islam tidak dapat dibiarkan begitu saja, namun membutuhkan dominasi yang besar dan mendalam terhadap 
ilmu-ilmu keislaman dan ilmuilmu yang berkapasitas sebagai alat untuk menganalisis seperti matematika, pengukuran, rasional dan ushul fiqh, dengan alasan bahwa masalah keuangan Islam penting untuk aspek keuangan interdisipliner (Rianto dan Amalia, 2010:7).

2. Ekonomi Islam menurut Yusuf Qardhawi adalah sistem-sistem ekonomi yang berdasarkan ketuhanan dan tidak lepas dari syariat Islam. (Dr. Mardani, 2017: 180).

Definisi Ekonomi Islam menurut pakar ekonomi Islam :

1. Sesuai buku M. Umer Chapra yang berjudul "Islam and the Islamic Challenge" dalam bahasa Indonesia berjudul "Islam dan Tantangan Ekonomi” menjelaskan bahwa manusia adalah individu pelaku ekonomi dengan perspektif dan anggapan mereka atau asumsi tentang alam dan gagasan tentang dunia. (Anindya aryu inayati, 2013:3-4).

2. Khursid Ahmad berpendapat bahwa, ekonomi Islam adalah jenis usaha untuk memahami perilaku manusia dan masalah moneter yang menangani masalah tersebut seperti yang ditunjukkan oleh pandangan Islam. (Dr. Mardani, 2017: 180).

Dari pengertian yang berbeda di atas, cenderung dikatakan bahwa ekonomi Islam adalah ilmu yang mempelajari berbagai macam tingkah laku manusia serta masalah moneter sesuai dengan premis pelajaran yang ketat untuk mencapai dunia dan akhirat.

\subsection{Literatur Review}

Dalam penelitian ini memiliki kesamaan dan perbedaan dengan penelitian yang pernah dilakukan sebelumnya yang berjudul "Peran Mahasiswa dalam Pengembangan Jurusan Ekonomi Islam pada Fakultas Syariah dan Hukum UIN Alauddin Makassar" Ditulis oleh Ahmad Yamany Arsyad mahasiswa dari Universitas Islam Negeri (UIN) Alauddin Makassar prodi Ekonomi Islam diterbitkan pada tahun 2010. Peran mahasiswa dalam perkembangan aspek keuangan syariah dipengaruhi oleh beberapa faktor pendorong dan penghambat. Penelitian ini diarahkan untuk mengetahui peran mahasiswa serta beberapa faktor yang menjadi pendorong dan penghambat dalam perkembangan ekonomi syariah tersebut. Dalam situasi ini, kemajuan aspek ekonomi syariah di Fakultas Syariah dan Hukum UIN Alauddin Makassar sebagai objek penelitian. Penelitian yang dilakukan adalah jenis penelitian lapangan yang bisa disebut juga study kasus dengan menggunakan pendekatan deskriptif kualitatif. Hasil informasi dalam penelitian ini diperoleh melalui pengamatan, wawancara dan dokumentasi mengenai pengetahuan mahasiswa, kesadaran mahasiswa, dan kegiatan yang dilakukan oleh mahasiswa Fakultas Syariah dan Hukum UIN Alauddin Makassar dalam perkembangan ekonomi Islam. Penyusunan data dilakukan dengan cara altering, kategorisasi, dan interpretasi kemudian dianalisis dengan menggunakan metode pemeriksaan subyektif yang pasti. Hasil penelitian mengungkapkan bahwa peran yang dilakukan oleh mahasiswa dalam perkembangan ekonomi Islam dapat dilihat dari beberapa kajian, bahkan dapat membentuk organisasi kemahasiswaan yang menjurus kepada ilmu ekonomi Islam. Faktor pendorong 
pengembangan ekonomi Islam adalah kesadaran mahasiswa dan masyarakat akan keberhasilan ekonomi Islam dalam menghadapi berbagai permasalahan perekonomian. Sedangkan yang menjadi faktor penghambat perkembangan ekonomi Islam adalah tidak adanya bantuan material dan kurangnya kerjasama dengan pihak yang terkait. Berdasarkan skripsi dari Ahmad Yamany Arsyad yang berjudul "Peran Mahasiswa dalam Pengembangan Jurusan Ekonomi Islam pada Fakultas Syariah dan Hukum UIN Alauddin Makassar", menjelaskan tentang peran mahasiswa serta faktor pendorong dan penghambat dalam perkembangan ekonomi Islam. Objek yang digunakan sebagai penelitian adalah Fakultas Syariah dan Hukum UIN Alauddin Makassar. Perbedaan dengan penelitian yang kami lakukan adalah kami menggunakan mahasiswa Fakultas Ekonomi Universeitas Islam Majapahit sebagai objek penelitian. Kami menggunakan metode kualitatif dengan, sehingga dapat diketahui bagaimana peran yang dilakukan oleh mahasiswa dalam perkembangan terhadap Ekonomi Islam di Universitas Islam Majapahit. Kami juga akan mengetahui sejauh mana mahasiswa Fakultas Ekonomi Universitas Islam Majapahit dalam memahami dan menerapkan Ekonomi Islam pada kehidupan sehari-harinya. Sehingga faktor pendorong dan penghambat dalam perkembangan Ekonomi Islam di Universitas Islam Majapahit akan terlihat dengan lebih jelas.

Selain itu, ada lagi yang melakukan penelitian sebelumnya dengan judul " Peranan Mahasiswa Program Studi Ekonomi Islam Ususka Riau dalam Mengembangkan Ekonomi Islam". Peranan seorang mahasiswa sangat dibutuhkan, dimana mahasiswa dalam situasi seperti ini berperan penting atau menjadi tolak ukur bagi masyarakat yang belum memahami apa itu ekonomi Islam sebenarnya. Bentuk peranan yang dapat mendukung mahasiswa untuk mengembangkannya, yaitu mahasiswa harus memerankan dan memimpin dalam praktik ekonomi syariah, mahasiswa memberikan edukasi kepada masyarakat umum, secara keseluruhan mahasiswa dianggap lebih tanggap dalam menguasai ekonomi syariah daripada golongan masyarakat umum dan juga mahasiswa harus memberikan dorongan kepada masyarakatumum dalam mempelajari dan menerapkan sistem ekonomi syariah dalam kehidupan sehari-hari. Peran Mahasiswa dipengaruhi oleh segi pendorong dan penghambat. Salah satu cara mahasiswa dalam membina sistem Ekonomi Islam adalah dengan mensosialisasikan ekonomi Islam baik di dalam lingkungan Universitas maupun di lingkungan umum, misalnya melaksanakan workshop dilingkungan Universitas diantaranya seminar Ekonomi Kerakyatan yang diadakan oleh HMJ-EI (Himpunan Mahasiswa Jurusan Ekonomi Islam) dan KOMISARIAT HMI (Himpunan Mahasiswa Islam) yang dilaksanakan pada tanggal 18 Desember 2007 di kampus UIN Suska RiauPekanbaru.

\subsection{Metode Penelitian}

Seperti yang ditunjukkan oleh Bogdan dan Taylor (1975:5) sebagaimana dikutip oleh Moleong mencirikan kualitatif sebagai strategi observasi yang menghasilkan informasi deskriptif yang disusun atau berupa lisan yang diperhatikan dari individu dan perilakunya. Metodologi ini ditujukan pada situasi dan individu secara komprehensif (keseluruhan). Sementara itu, Kirk dan Miller (1986:9) berpendapat bahwa kualitatif adalah kebiasaan khusus dalam ilmu 
masyarakat yang umumnya bergantung pada orang-orang di wilayah mereka sendiri dan berhubungan dalam percakapan dan ungkapan mereka.

\section{Lokasi Penelitian}

Lokasi penelitian ini dilakukan di Fakultas Ekonomi Universitas Islam Majapahit. Lokasi penelitian ini dipilih karena berpotensi dalam perkembangan ekonomi islam kedepannya.

\section{Jenis dan sumber penelitian}

Jenis data yang dicari dalam penelitian ini adalah kegiatan yang berhubungan dengan ekonomi Islam yang ada di lingkungan universitas Islam Majapahit, Data tentang pengetahuan beberapa mahasiswa mengenai ekonomi islam, faktor pendorong dan penghambat dalam ekonomi islam, kesadaran mahasiswa dalam perkembangan ekonomi Islam. Sumber data yang diperoleh, yakni:

a. Data Primer diperoleh berdasarkan observasi, wawancara dan dokumentasi yang dilakukan dengan beberapa responden

b. Data Sekunder yang diperoleh berdasarkan referensi-referensi yang berkaitan dengan penelitian ini.

\section{Subyek dan obyek penelitian}

Subyek penelitian ini adalah beberapa mahasiswa Fakultas Ekonomi Universitas Islam Majapahit sebagai responden. Obyek penelitian ini adalah peran mahasiswa Fakultas Ekonomi Universitas Islam Majapahit dalam perkembangan ekonomi islam.

\section{Teknik Pengumpulan data}

Dalam pengumpulan data dilakukan dengan cara mengamati kegiatan yang berlangsung di GI BEI Unim, mengikuti pembelajaran mata kuliah manajemen syariah serta melakukan wawancara virtual dengan beberapa mahasiswa fakultas ekonomi Universitas Islam Majapahit untuk mengetahui seberapa jauh pengetahuan mahasiswa tentang ekonomi islam. Dokumentasi diperoleh dari hasil observasi kegiatan yang diamati serta tangkapan layar pada saat melakukan wawancara virtual.

\subsection{Hasil Penelitian Dan Pembahasan}

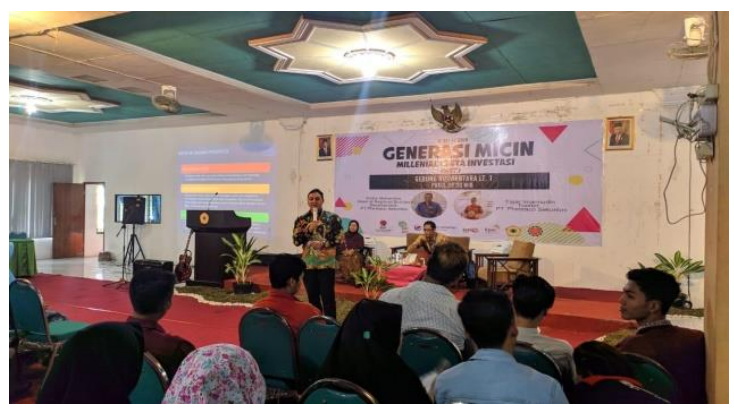

Gambar 1. Berlangsungnya acara seminar di Gedung Nuswantara Lt. 1 UNIM

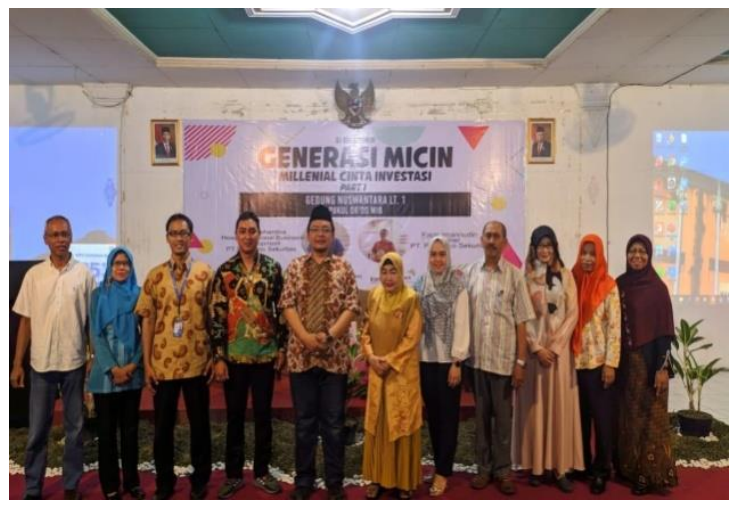

Gambar 2. Foto bersama Bapak/Ibudosen dengan pengisi acara seminar selesai 


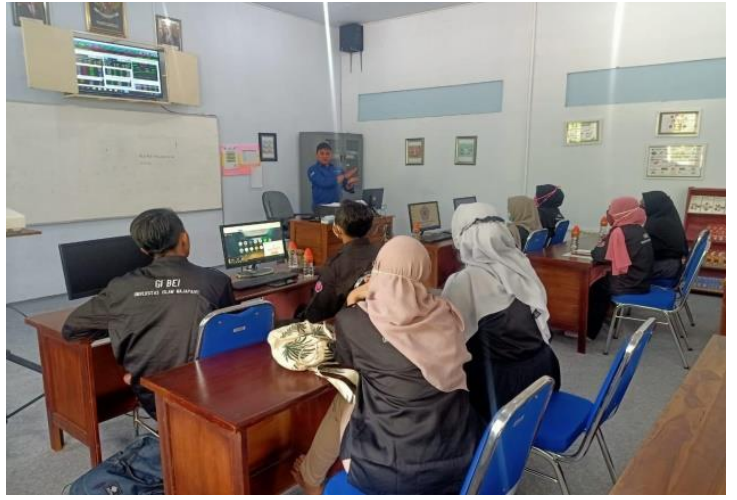

Gambar 3. Kegiatan Bimbingan dalam Organisasi GI BEI di UNIM

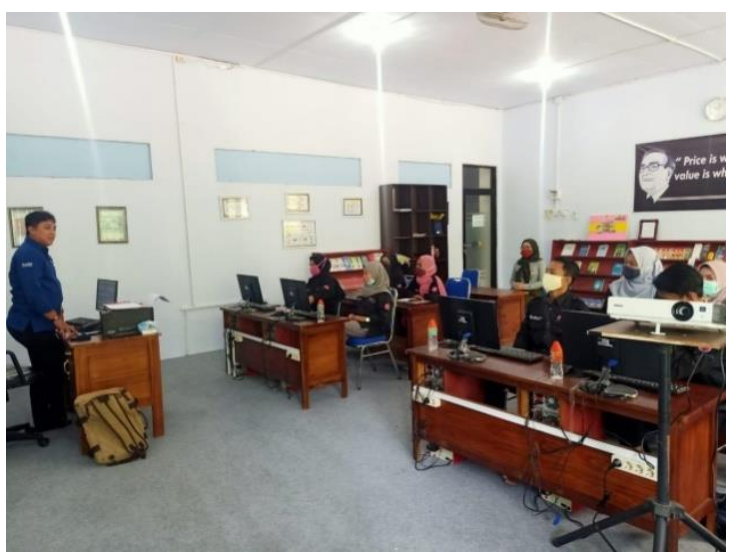

Gambar 4. Kegiatan Bimbingan dalam Organisasi GI BEI di UNIM

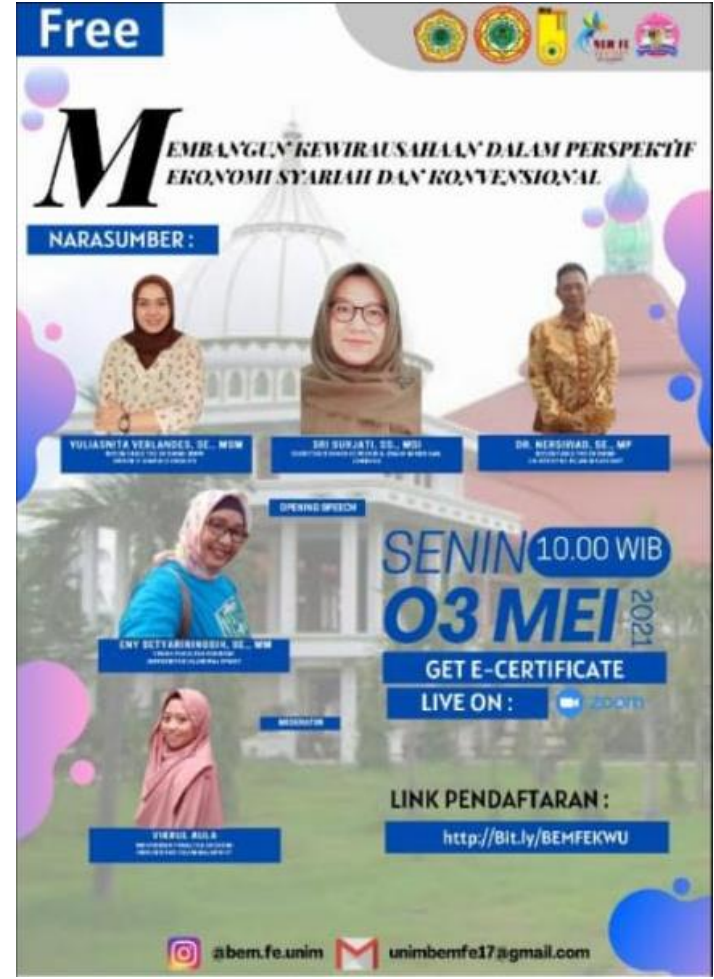

Gambar 5. Webinar "Membangun Kewirausahaan Dalam Perspektif Ekonomi Syariah \& Konvensional" pada 3 Mei 2021 yang diselenggarakan oleh BEM Fakultas Ekonomi Universitas Islam Majapahit.

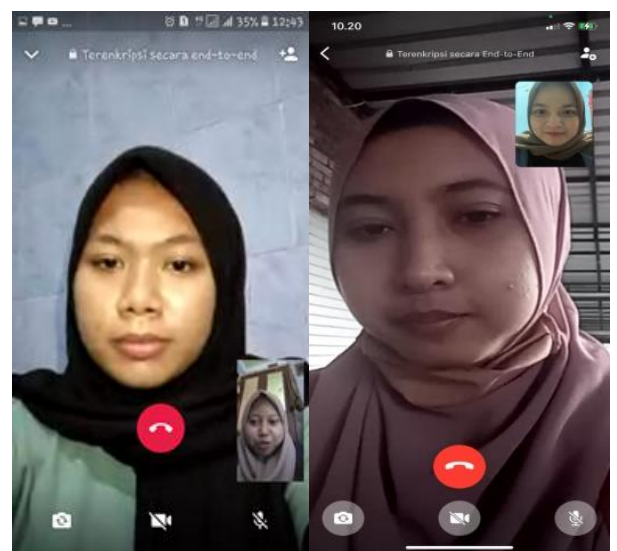

Gambar 6. Beberapa Responden Saat Melakukan Wawancara Secara Virtual

Berdasarkan hasil uji observasi serta wawancara virtual dapat dipaparkan bahwa peran mahasiswa yang dapat dilakukan untuk proses perkembangan ekonomi Islam di Universitas yaitu ikut mengembangkan ekonomi syariah dengan sering menyelenggarakan webinar atau seminar- 
seminar di Universitas Islam Majapahit, melakukan bisnis dengan mengikuti ajaran Islam atau bisa membentuk organisasi kemahasiswaan yang berhubungan dengan ilmu ekonomi Islam, di Universitas Islam Majapahit sendiri ada organisasi yang dimaksud seperti UKM (Unit Kegiatan Mahasiswa) Kewirausahaan. Dan juga ada organisasi yang berhubungan dengan investasi yaitu, Galeri Investasi Bursa Efek Indonesia atau yang disebut GI BEI. Dengan dibentuknya organisasi-organisasi seperti ini yaitu dapat menanamkan jiwa investasi pada diri mahasiswa, khususnya untuk fakultas ekonomi bisa meningkatkan nilai aset dan kekayaan, menyiapkan masa depan yang cerah, dapat membimbing berinvestasi secara halal dan sebagai seorang mahasiswa yang belum terjun didunia kerja, kita hanya bisa mempelajari apa itu ekonomi islam dan bagaiamana praktiknya. Teori-teori tersebut tentunya menjadi bekal untuk kita memasuki dunia kerja kita suatu saat nanti.

Peran yang bisa dilakukan oleh mahasiswa dalam mengembangkan ekonomi Islam yaitu mahasiswa harus dapat memerankan dan menjadi pemimpin dalam praktik ekonomi Islam. Seperti mahasiswa dapat memperjual-belikan barang-barang yang halal dan bisa mengelola keuangan tanpa riba, melakukan sewa menyewa dengan benar sesuai dengan prinsip syariah. Dan setelah lulus kuliah harus tetap melaksanakan perannya karena kewajiban setiap muslim untuk melaksanakan ekonomi harus sesuai syariah Islam, sebab masyarakat nantinya akan melihat secara langsung praktik ekonomi Islam dan kebaikan yang dihasilkan. Selanjutnya mahasiswa sebagai kelompok yang terpelajar harus bisa memberikan edukasi kepada masyarakat umum, karena secara keseluruhan mahasiswa dianggap lebih tanggap dalam mempelajari ekonomi Islam ini dan bisa memberikan motivasi kepada masyarakat umum betapa pentingnya menerapkan sistem ekonomi Islam dalam kehidupan. Selain itu, mahasiswa harus terus berupaya dengan memberdayakan percepatan penerapan kesadaran sehingga bisa terwujud dalam lingkungan masyarakat dengan tegaknya sistem kehidupan Islam. Dipercaya bahwa mahasiswa dapat meningkatkan perannya dalam membangun perkembangan ekonomi Islam dan dapat melahirkan kepribadian yang peduli terhadap kehidupan bangsa serta membantu memecahkan masalah-masalah yang dihadapi negara Indonesia. (Kurnia Abdi Putri, 2012: 26-28).

Adapun beberapa faktor pendorong dan penghambat dalam perkembangan ekonomi Islam yaitu:

\section{Faktor pendorong}

Semakin banyaknya transaksi perdagangan, Indonesia merupakan penduduk dengan mayoritas beragama Islam ini dapat memudahkan untuk memahami ekonomi sesuai syariah islam. Dan di Universitas sendiri diberikannya mata kuliah manajemen syariah khususnya untuk fakultas ekonomi untuk dipelajari dan diterapkan dalam kehidupan sehari-hari. Mahasiswa sebagai faktor pendukung harus bisa menerapkan dengan baik, agar bisa terwujud sistem ekonomi berbasis syariah ini.

2. Faktor penghambat

Kurangnya minat dan kesadaran mahasiswa dalam mempelajari dan menerapkan ekonomi Islam dalam kehidupan sehari-hari. Kita bisa lihat juga masih banyak orang yang berbuat curang dalam perdagangan, minimnya pengetahuan mengenai ekonomi Islam dan juga sumber daya manusia di Indonesia masih dibilang rendah. Karena jika kita saja tidak tahu atau kurang memahami apa itu ekonomi Islam, bagaimana kita akan menerapkan dengan baik. Maka dari itu kita sebagai mahasiswa harus 
mempelajari lagi ekonomi Islam itu seperti apa. Faktor penghambat juga bisa dari internal maupun eksternal. Internal bisa dari diri kita sendiri, jika kita malas atau kurang minat untuk belajar apa pentingnya peran kita terhadap perkembangan ekonomi Islam maka tidak akan ada hasil. Faktor eksternal sendiri pun bisa dari lingkungan sekitar yang bisa mempengaruhinya. Dan bisa juga negara kurang mendukung dengan perkembangan ekonomi Islam itu sendiri.

Peran Mahasiswa sendiri dinilai sangat penting untuk mengembangkan atau meningkatkan ekonomi islam. Dengan melakukan perkembangan tentu saja harus melalui beberapa faktor yaitu faktor pendorong dan penghambat. Mahasiswa merupakan generasi penerus bangsa yang memiliki peran penting dalam masa depan negara selanjutnya. Diharapkan dengan kegiatan ini dapat melahirkan karakter mahasiswa yang peduli dengan bangsa dan negara.

Berdasarkan hasil penelitian yang dilakukan oleh penulis melalui proses wawancara mengenai peran mahasiswa terhadap kegiatan ekonomi islam serta apa saja yang menjadi faktor pendorong dan penghambat sebagai berikut, jawaban yang di dapat dari Ernaningsih mengatakan :

"Menurut saya pertama yang dilakukan adalah dengan pengembangan produk dan pasar. Target dari pengembangan ini adalah untuk menciptakan produk ekonomi islam dan instrumen likuiditas demi pendalaman ilmu pengetahuan.Kedua adalah pengembangan sumber daya manusia dan market empowerment. Pengembangan sumber daya manusia ini dilakukan dengan mendorong pendidikan untuk meningkatkan kompetensi tenaga kerja terutama pada ekonomi islam. Faktor terbesar yang bisa menjadi pendorong dan penghambat adalah masyarakat itu sendiri".
Dan jawaban lain didapat dan diperkuat dari mahasiswa lainnya yang sedikit berbeda dari jawaban sebelumnya, jawaban dari Astria mengatakan :

"Peran saya terhadap pengembangan ekonomi islam adalah dengan mempelajari mata kuliah manajemen syariah dan menerapkannya dengan baik dalam kehidupan sehari-hari dan melakukan seminar-seminar tentang ekonomi islam dan juga melakukan penelitian di lembagalembaga perbankan dengan cara menerapkan sistem-sitem yang ada dalam perdagangan islam. Faktor yang menjadi penghambatnya karena banyak masyarakat yang kurang memahami istilah ekonomi syariah dan juga karena SDM di Indonesia masih rendah sedangkan faktor pendorongnya adalah memperkuat permodalan sehingga bisa seperti bank konvensional serta melengkapi fasilitas layanan".

Azizah menjawab pertanyaan yang sama peran saya yaitu dengan mengikuti seminar-seminar tentang ekonomi islam dan ikut mengembangkan ekonomi islam. Faktor penghambatnya banyaknya orangorang yang berbuat curang dalam bidang perekonomian. Pada era sekarang yakni di era 4.0 banyak sekali para pebisnis melakukan segala cara agar bisnis tetap berjalan meski di dalam proses tersebut banyak sekali yang bertentangan dengan hukum islam. Dan sebagai faktor pendorongnya yaitu sumber daya manusia di masa yang akan datang. Dengan adanya banyak sekali universitas yang memiliki program studi mengenai ekonomi islam, maka dengan sumber daya manusia tersebut akan berkembang dan lebih banyak lagi yang mengerti apa itu ekonomi islam".

Dan jawaban yang didapat dari Ilsahatin mengatakan :

"Dengan mengetahui makna sebenarnya apa itu perkembangan ekonomi islam. Jika saya tidak tahu apa atau bagaimana perkembangan ekonomi islam, 
maka bagaimana saya bisa terapkan? Maka dengan itu saya lebih mempelajari lagi apa itu perkembangan ekonomi islam dan akan berlanjut menerapkan beberapa aturan islam dalam berniaga. Untuk faktor pendorong ekonomi islam adalah adanya larangan riba sehingga masyarakat ekonomi rendah terhindar dari adanya bunga yang menyebabkan kemiskinan. Adanya sekularisme sehingga pemerintahan dan agama harus dipisah, hal itu yang menyebabkan terhambatnya pengembangan ekonomi islam itu sendiri'.

Dan jawaban yang didapatkan dari keempat mahasiswa peneliti menyimpulkan bahwa mahasiswa memiliki peran penting dalam perkembangan ekonomi islam yang ada di Universitas Islam Majapahit

\subsection{Kesimpulan}

1. Mahasiswa fakultas ekonomi Universitas Islam Majapahit memiliki peran penting dalam perkembangan ekonomi islam, hal tersebut dikarenakan sebagai mahasiswa fakultas ekonomi yang berada di Universitas Islam memiliki pengaruh karena telah digaris bawahi sebagai generasi penerus bangsa dan sebaiknya turut serta membantu perkembangan ekonomi Islam tersebut. Yang dapat dilakukan adalah mengikuti atau menerapkan nilai-nilai yang bersumber dari Alqur'an dan hadits berupa prinsip-prinsip universal. Terutama pada nilai-nilai dan etika yang terkandung dalam setiap kegiatan ekonomi yang berfokus islam tersebut. Dalam perkembangan ekonomi islam, yang berperan tidak hanya pakar ahli ekonomi islam saja tetapi mahasiswa juga memberikan peran yang tidak sedikit. Hal ini bisa dilihat dari kegiatan-kegiatan yang dilakukan mahasiswa terkait perkembangan ekonomi islam.

Dalam perkembangan ekonomi islam terdapat beberapa faktor pendorong dan faktor penghambat yaitu pengembangan sumber daya manusia dan market empowerment. Pengembangan sumber daya manusia ini dilakukan dengan mendorong pendidikan untuk meningkatkan kompetensi tenaga kerja terutama pada ekonomi islam. Faktor penghambat juga bisa disebabkan karena banyak masyarakat yang kurang memahami istilah ekonomi syariah dan juga karena SDM di Indonesia masih rendah, masih banyak orang-orang yang berbuat curang dalam bidang perekonomian. Pada era sekarang yakni di era 4.0 banyak sekali para pebisnis melakukan segala cara agar bisnis tetap berjalan meski di dalam proses tersebut banyak sekali yang bertentangan dengan hukum islam, Adanya sekularisme sehingga pemerintahan dan agama harus dipisah. Dan untuk faktor pendorong bisa dilakukan dengan memperkuat permodalan sehingga bisa seperti bank konvensional serta melengkapi fasilitas layanan, sumber daya manusia di masa yang akan datang dengan adanya banyak sekali universitas yang memiliki program studi mengenai ekonomi islam, maka dengan sumber daya manusia tersebut akan berkembang dan lebih banyak lagi yang mengerti apa itu ekonomi islam.

\section{DAFTAR PUSTAKA}

Arsyad, A. Y. (2010). Peran Mahasiswa dalam Pengembangan Jurusan Ekonomi Islam Pada Fakultas Syariah dan Hukum UIN Alauddin Makassar (Doctoral dissertation, universitas Islam Negeri Alauddin Makassar).

Putri, K. A. (2012). Peranan Mahasiswa Program Studi Ekonomi Islam UIN SUSKA RIAU Dalam Mengembangkan Ekonomi Islam (Doctoral dissertation, Universitas Islam Negeri Sultan Syarif Kasim Riau).

Syakur, A. (2018). Ruang lingkup ekonomi islam. Jurnal Studi Islam: Pancawahana, 13(2), 66-79.

Dr. Mardani, cetakan ke-2, Januari (2019). Pendidikan Agama Islam untuk 
Perguruan Tinggi. Jakarta: PRENADAMEDIA GROUP (Divisi Kencana).

Syafrudin, U., \& Widagdo, R. (2016). Peran Perguruan Tinggi Islam Dalam Kontek Ekonomi Islam Terhadap Pengembangan Kurikulum Jurusan Perbankan Syari'ah. Al-Amwal: Jurnal Ekonomi dan Perbankan Syari'ah, 8(2).

Rohmah, U. (2017). Analisis peran ekonomi kreatif dalam peningkatan pendapatan pengrajin ditinjau dari perspektif ekonomi Islam (Studi Pada Industri Anyaman Bambu Desa Tulungagung Kecamatan Gadingrejo Kabupaten Pringsewu) (Doctoral dissertation, UIN Raden Intan Lampung).

Idri, H. (2010). Hadis Ekonomi: Ekonomi dalam Perspektif Hadis Nabi. Kencana.

Anshori, M., \& Iswati, S. (2019). Metodologi penelitian kuantitatif: edisi 1. Airlangga University Press.

Inayati, A. A. (2013). Pemikiran Ekonomi Islam M. Umer Chapra. Profetika: Jurnal Studi Islam, 14(2), 164-176.

Gumati, R. W. (2019). Studi Deskriftif Peran Mahasiswa dalam Pemberdayaan Ekonomi Syari'ah Pada Masyarakat Pedesaan. Al Amwal (Hukum Ekonomi Syariah), 2(1), 113.

Lantaeda, S. B., Lengkong, F. D., \& Ruru, J. (2017). Peran Badan Perencanaan Pembangunan Daerah Dalam Penyusunan RPJMD Kota Tomohon. Jurnal Administrasi Publik, 4(48).

Zelika, A., Koagouw, F. V., \& Tangkudung, J. P. M. (2017). Persepsi Tentang Perayaan Pengucapan Syukur Minahasa (Studi Komunikasi Antar Budaya Pada Mahasiswa Luar
Sulawesi Utara Di Fispol. Acta Diurna Komunikasi, 6(1).

Kurnia, H. (2014). Pengaruh Keaktifan Berorganisasi Terhadap Indeks Prestasi Kumulatif Mahasiswa Universitas Cokroaminoto Yogyakarta. Academy of Education Journal, 5(2).

Hamid, A. (2018). Aktualisasi Manajemen Peningkatan Mutu Berbasis Madrasah. At-Ta'lim: Jurnal Pendidikan, 4(1), 1-20.

Febriani, N., \& Fadilah, E. (2019). Penerapan Model Monetisasi Content Creation Pada Vice Indonesia. Jurnal Kajian Jurnalisme, 2(2). 